Tetranychus or red spider is preyed upon by 4 species of Arthrocnodax and 1 of Mycodiplosis. It will be seen by referring to the above tabulation, that Arthrocnodax displays a marked partiality for the Acarina.

The plant mites or Eriophyidæ are preyed upon by 1 species of Endaphis and 1 of Arthrocnodax.

A species of gall midge, genus unknown, has been reared or was supposed to have been reared from the eggs of the periodical Cicada, Tibicen septemdecim.

It appears very probable from the above records, particularly in connection with the observations of Mr. E. A. MacGregor upon Arthrocnodax carolina, that the value of certain gall midges as natural enemies has been largely overlooked. There are probably a considerable number of other species, presumably mostly undescribed, which have similar habits.

\title{
ON THE ORIGINAL HABITAT OF STOMOXYS CALCITRANS
}

By F: MuIR, Taihoku, Japan

In his interesting article on the geographical distribution of the stable fly, ${ }^{1}$ Prof. C. T. Brues writes that "it is probably a native of the old world, most likely of central Europe," and, near the end, "It is probably native to the palæarctic region from whence it has followed man in his migrations to all parts of the world."

I am not able to follow Mr. Brues in these conclusions, and as they are of some importance in economic entomology, when endeavoring to discover parasites to control this pest, I would like to state my reasons for differing from an authority who has given this species a great deal of study.

In judging of the native habitat of a widely distributed insect like S.calcitrans, there are two points that I consider necessary to take into consideration: (1) the center of activity of the genus as indicated by the geographical distribution of the species of the genus; (2) the number and specialization of the natural enemies of the species under consideration, and its relative abundance in the different regions.

Turning to Brues' list of species of Stomoxys, and, if we leave out of consideration calcitrans, which is world wide, nebulosa, which is doubtful, and pallida, which is without given habitat, we have twentyeight species, all of which belong to the Oriental and Ethiopian regions. Nine are native to India and Ceylon, and two a little to the east; fourteen to the African mainland and three to neighboring islands.

${ }^{1}$ Jour. Econ. Ent., Vol. 6, No. 6, 1913, pp. 459-477. 
From this it appears that the center of activity of this genus is within the Indo-Ethiopian region, and, therefore, calcitrans is more likely to have arisen within this region than independently within the palcearctic.

Little is known of the parasites of this insect, especially in the Ethiopian region, but from my own observations in various parts of Africa I should say that it is less abundant there than in many extra-tropical places I have collected in. Seeing that the climatic conditions in Africa are more favorable than in temperate climates, the less abundance of this insect there may possibly be due to the presence of parasites. .

Whether India or Africa was the birthplace of this species, it is difficult to judge, as there is no evidence to judge by, but my personal belief, unsupported by any direct evidence, is that the honor (or dishonor) should be given to Africa.

\section{A NEW CECIDOMYIID FLY}

\section{By T. D. A. Cockerelu, Boulder, Colorado}

On July 15, 1913, I observed a large number of small gnats hovering over flowers of Japanese Iris, in the grounds of Mr. D. M. Andrews, about three miles east of Boulder, Col. These prove, on examination, to represent a new species of the interesting genus Microcerata Felt.

\section{Microcerata jridis n. sp.}

Male. Length nearly $2 \mathrm{~mm}$.; reddish brown, with the legs cream-color; thorax redder than abdomen, the latter dilute sepia; wings clear hyaline with very pale veins; antennæ 9 jointed, the last three joints more slender than those before; palpi 4 jointed, the last joint very long. Very close to $M$. spinosa Felt, with the antennæe and palpi practically as in that species; but distinguished by the much larger size, pallid legs, subcosta joining costa before middle of wing; basal segment of clasp of genitalia swollen apically, terminal segment subbulbous basally and sharply bent apically, style as long as first segment of clasp. The following measurements are in microns: width of second antennal joint, 51 ; width of third, 37 ; width of ninth, 16 ; length of last palpal joint, 82; length of last segment of clasp, 75.

This is quite close to the fossil Lithomyza Scudder, but has the venation more modified from the supposedly primitive type.

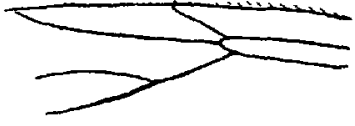

a

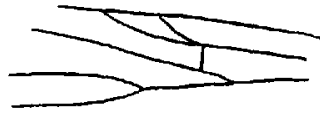

b

Fig. 29-Portion of venation; a Microcerata iridis, b Lithomyza condita (latter after Scudder) 